\title{
PROMOSI DIGITAL UNTUK WISATAWAN RUSIA
}

\author{
Ni Luh Made Vinaya Medhiatika \\ Fakultas Ekonomi dan Bisnis, Universitas Sahid, Jakarta \\ Jl. Soepomo No 84, Jakarta Selatan \\ Email Korespondensi: madevinaya@gmail.com
}

\begin{abstract}
ABSTRAK
Setiap tahun, Kementrian Pariwisata memiliki target kunjungan wisatawan mancanegara. Tujuan dari kajian ini adalah untuk menentukan strategi promosi yang sesuai dengan perilaku wisatawan mancanegara terutama wisatawan Rusia. Data untuk kajian ini merupakan data sekunder yang sudah dihimpun oleh Kementrian Pariwisata. Objek kajian ini adalah wisatawan mancanegara dari Rusia yang sudah maupun akan berlibur ke Indonesia. Metode yang digunakan termasuk dalam metode eksploratif sehingga data tentang perilaku dan promosi yang sudah ada dapat lebih dipahami. Berdasarkan perilaku dan tingkat penggunaan sosial media wisatawan Rusia maka hasil yang didapat promosi pariwisata yang cocok adalah promosi digital melalui sosial media, terutama sosial media yang terpopuler di Rusia yaitu Vk.com. Melalui sosial media ini kriteria social strategy dan digital tourism, dapat terlaksana. Akun promosi di Vk.vom menampilkan foto dan video tentang budaya desa maupun perkotaan serta keindahan bahari di Indonesia. Wisatawan Rusia pun dapat menunggah foto, video, dan ulasan pengalaman selama berlibur di Indonesia.
\end{abstract}

Kata kunci: promosi, sosial media, wisatawan, Rusia

\begin{abstract}
Every year, the Ministry of Tourism has a target for number of visit from International tourist. Objectives of this study is to select the right strategy that fit with Russian tourists. Sources of secondary data for this study collected by Ministry of Tourism. The objects are Russian travelers that traveled or planning their holiday to Indonesia. This study used explorative methods to discover Russians' behavior and promotion tools that fit with them. As result, based on their behavior and social media use, decided that digital promotion through social media is the suitable strategy, specifically by the most popular social media in Russia, Vk.com. Within this social media, all criteria of social strategy and digital tourism can be delivered. Indonesia's account on Vk.com must contains images and videos about culture and nautical beauty of Indonesia. Russian travelers also can upload their images, video, and reviews about their holiday experienced in Indonesia.
\end{abstract}

Keywords: promotion, social media, tourist, Russia 


\section{PENDAHULUAN}

Kementrian Pariwisata memiliki target kunjungan sebanyak 15 juta wisatawan mancanegara (wisman) ke Indonesia selama tahun 2017. Untuk mewujudkan target kunjungan wisman, Kementrian memerlukan strategi promosi yang jitu dimana strategi tersebut harus sesuai dengan profil negara dan perilaku wisatawannya. Wisatawan mancanegara dipetakan menurut negaranya yang terdiri atas; pasar Eropa 1, pasar Eropa 2, pasar Amerika Serikat, pasar Timur Tengah, pasar Australia, pasar India, pasar Singapura, pasar Malaysia, pasar Tiongkok, Pasar Filipina, pasar Thailand, pasar Korea, dan pasar Jepang. Pasar Eropa 1 sendiri terdiri atas negara; Inggris, Prancis, dan Rusia. Untuk kajian ini akan fokus pasar Rusia karena jika dilihat dari data yang ada merupakan pasar yang potensial sehingga membutuhkan promosi yang sesuai. Pada tahun 2017, Kementrian Pariwisata menargetkan 108.000 kunjungan wisman Rusia ke Indonesia. Pasar Rusia dikatakan potensial jika dilihat dari angka pertumbuhan outbound Rusia ke Indonesia pada tahun 2016-2017 berada di angka 22,54\%. Wisman Rusia menilai Indonesia sebagai negara yang kaya akan acara adat sehingga menjadi salah satu destinasi pilihan. Seperti yang sudah disebutkan diatas, kajian ini akan banyak menganalisis tentang perilaku wisatawan Rusia untuk menentukan perangkat promosi yang tepat guna.

Populasi negara Rusia sebesar 144,1 juta jiwa. Sebanyak lebih dari 10 juta jiwa tinggal di ibukota Rusia, Moskow. Pada tahun 2015, UNWTO mencatat total perjalanan keluar Rusia (outbound) sebanyak 21,8 juta jiwa. Jumlah kunjungan wisman Rusia ke Indonesia selama tahun 2015 hingga 2017 mengalami pertumbuhan hingga 54,49\%. Angka inilah yang menunjukkan potensi wisman Rusia untuk berkunjung ke Indonesia. Outbound Rusia tertinggi terjadi pada bulan Juli hingga September sejalan dengan berlangsungnya libur musim panas di negara tersebut. Destinasi utama wisman Rusia ke Indonesia adalah Bali, diikuti dengan kunjungan ke daerah lain seperti Batam dan Jakarta. Wisman Rusia yang berlibur ke Indonesia didominasi oleh kelompok umur 25-34 tahun dan 35-54 tahun. Mayoritas dari mereka merupakan Free Individual Traveler (FIT). Kedua kelompok umur diatas akan memilih aktivitas pedesaan dan perkotaan serta wisata bahari. Wisman Rusia akan tinggal selama 2 minggu dan selama di Indonesia akan memilih hotel bintang 5 sebagai tempat tinggalnya.

Perilaku wisatawan akan berpengaruh pada strategi promosi. Berikut penjabaran perilaku wisatawan Rusia berdasarkan sumber informasi, penggunaan internet, hingga aktivitas media sosial.

\begin{tabular}{|c|c|c|}
\hline (9) & Words of Mouth & $44.21 \%$ \\
\hline $\boldsymbol{e}$ & Other website & $40.00 \%$ \\
\hline$f$ & Social Media & $33.68 \%$ \\
\hline$\approx$ & Books \& Magazine & $16.84 \%$ \\
\hline e & Official Website & $12.63 \%$ \\
\hline 四 & Information Board & $8.42 \%$ \\
\hline 尚 & TV & $3.16 \%$ \\
\hline 圆 & News paper & $3.16 \%$ \\
\hline 百 & Brochure & $2.11 \%$ \\
\hline पृ & Radio & - \\
\hline (i) & Others & $3.16 \%$ \\
\hline
\end{tabular}

Gambar 1. Sumber Informasi Wisman Rusia

Sumber: Passenger Exit Survey Indonesia (2015) 
Gambar diatas menunjukkan bahwa 44\% dari wisman Rusia sangat mengandalkan sumber informasi melalui word-of-mouth dari keluarga atau teman untuk menentukan destinasi liburan. Wisman juga menjelajah situs-situs wisata serta menggali informasi dari sosial media.

\begin{tabular}{|c|c|c|c|c|c|c|}
\hline & \multirow{2}{*}{\multicolumn{2}{|c|}{ RUSSIA }} & \multirow{2}{*}{\multicolumn{2}{|c|}{ INDONESIA }} & \multirow[b]{3}{*}{ Europe Average } & \multirow{3}{*}{ Global Average } \\
\hline & & & & & & \\
\hline & Numbers & I Rank & Numbers & Rank & & \\
\hline Internet Penetration & $72 \%$ & $14^{\text {th }}$ & $34 \%$ & $29^{n}$ & $73 \%$ & $46 \%$ \\
\hline Growth in Internet Users & n.a & n.a & na & na & $4 \%$ & $10 \%$ \\
\hline Social Madia Use* & $48 \%$ & $15^{n}$ & $30 \%$ & $2 \sigma^{2}$ & $47 \%$ & $36 \%$ \\
\hline Growth in Social Media Users & n.a & n.a & $n a$ & $n a$ & $3 \%$ & $10 \%$ \\
\hline Mobile Social Use* & $30 \%$ & 248 & $25 \%$ & $26 *$ & $132 \%$ & $51 \%$ \\
\hline Growth in Mobile Social Use & n.a & n.a & na & $n a$ & $1 \%$ & $4 \%$ \\
\hline Mobile Us:* & $72 \%$ & 192 & $63 \%$ & $2 \pi$ & $36 \%$ & $27 \%$ \\
\hline Growth in Mobil9 Use & n.a & n.a & na & na & $6 \%$ & $17 \%$ \\
\hline
\end{tabular}

Gambar 2. Gaya Hidup Digital Wisman Rusia

Sumber: We Are Social (2016)

Gambar 2 diatas memperlihatkan gaya hidup digital wisman Rusia cukup tinggi jika dibandingkan dengan rata-rata gaya hidup digital di Eropa apalagi jika dibandingkan dengan Indonesia. Penetrasi internet di Rusia sebesar 72\% atau berada pada peringkat 14 dunia. Penggunaan sosial media mencapai $48 \%$ yang menjadikan Rusia peringkat 15 dunia. Selanjutnya, tingkat penggunaan ponsel untuk bersosial media ( mobile social use) sebanyak $30 \%$ menempati urutan ke 24 . Terakhir, gaya hidup dengan menggunakan perangkat mobile sendiri sebesar $72 \%$ atau peringkat 19 dunia.

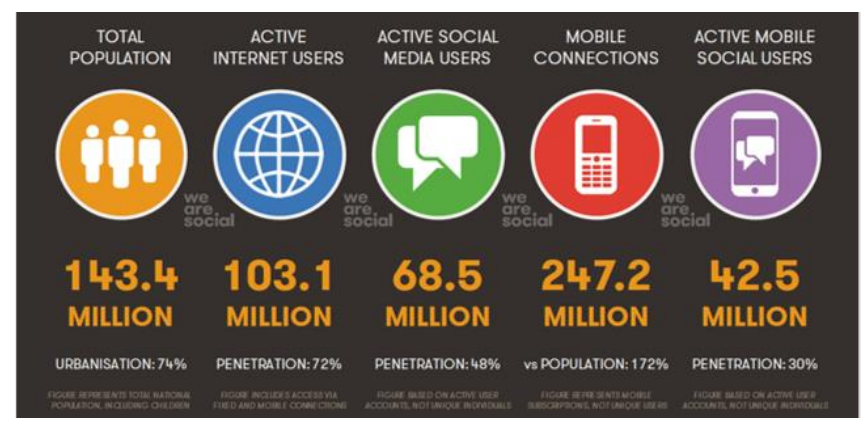

Gambar 3. Gaya Hidup Digital Di Rusia

Sumber: We Are Social (2016)

Gambar 3 menampilkan gaya hidup digital wisman Rusia jika dilihat dari jumlah populasinya. Populasi Rusia berjumlah 143, 4 juta jiwa dimana 103,1 rakyatnya merupakan pengguna aktif internet. Penggunaan internet akan diikuti dengan penggunaan sosial media dimana tercatat sebanyak 68,5 juta aktif sebagai pengguna sosial media. Pengguna perangkat mobile baik telepon pintar, tablet, dan sejenisnya sebanyak 247,2 juta bahkan lebih besar dari jumlah populasinya. Data mencatat, sebanyak 43,5 juta jiwa menggunakan ponsel atau tablet untuk bersosial media. 


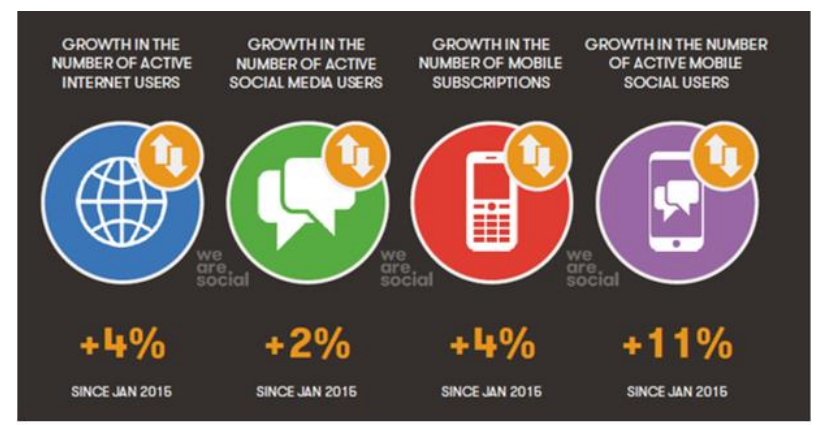

Gambar 4. Tren Pertumbuhan Digital

Sumber: We Are Social (2016)

Tren pertumbuhan digital di Rusia dapat dilihat pada gambar 4. Sejak bulan Januari 2016, jumlah pengguna aktif internet tumbuh sebanyak 4\%. Pertumbuhan juga terjadi pada pengguna aktif sosial media sebesar $2 \%$. Pertumbuhan jumlah pendaftar perangkat mobile juga naik $4 \%$. Kenaikan terbesar sebanyak $11 \%$ ada pada pengguna perangkat mobile untuk bersosial media.

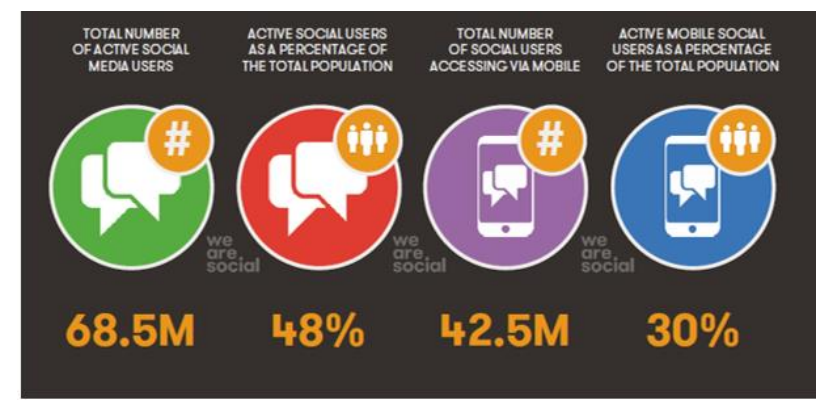

Gambar 5. Jumlah Pengguna Sosial Media di Rusia

Sumber: We Are Social (2016)

Seperti yang sudah disinggung sebelumnya, penetrasi internet dan perangkat mobile mendorong aktifnya penggunaan sosial media. Gambar 5 diatas menampilkan jumlah total pengguna aktif sosial media sebanyak 68,5 juta pengguna. Jumlah pengguna tersebut mencakup $48 \%$ dari total populasi Rusia. Sosial media dapat diakses melalui personal computer, laptop, ponsel, atau tablet. Perangkat mobile seperti ponsel atau tablet inilah yang menjadi pilihan bagi 42,5 juta pengguna untuk mengakses sosial media. Jumlah tersebut merupakan $30 \%$ dari total populasi.

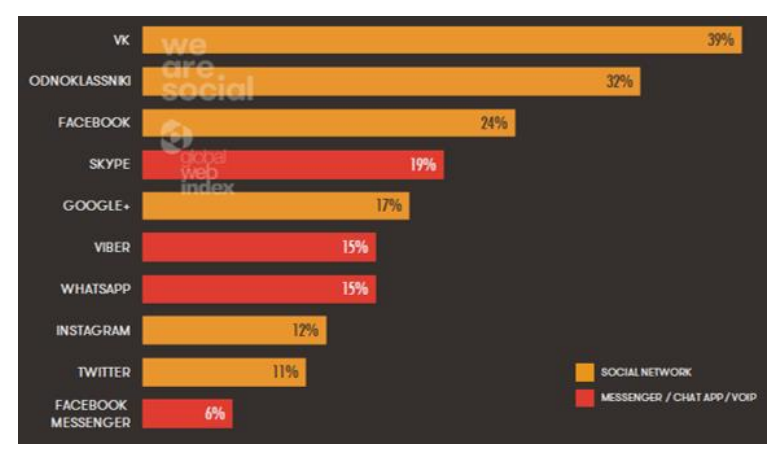

Gambar 6. Pilihan Sosial Media

Sumber: We Are Social (2016) 
Banyaknya jumlah pengguna aktif media sosial menghasilkan daftar platform atau laman sosial media yang banyak digunakan oleh wisman Rusia. Gambar 6 menunjukkan $39 \%$ pengguna aktif mengakses VK. VK.com merupakan sosial media semacam Facebook yang asli buatan Rusia. Jaringan sosial lain yang banyak digunakan adalah Odnoklassniki (Ok.ru) sebanyak 32\% dan Facebook berada di urutan ke-3 dengan 24\% pengguna aktif dari Rusia. Selain jaringan sosial adapula jaringan yang digunakan dalam bertukar pesan atau messager yang hampir secara merata digunakan wisman Rusia mulai dari Skype, Whatsapp, hingga Facebook Messenger. Perilaku wisatawan tidak terlepas dari segmen usia. Tabel dibawah ini menampilkan kelompok umur wisatawan Rusia.

Tabel 1. Distribusi Wisman Berdasarkan Kelompok Umur

\begin{tabular}{|c|c|c|c|c|c|c|c|}
\hline \multirow{2}{*}{ Rusia } & \multicolumn{9}{|c|}{ Kelompok Umur } & \multicolumn{2}{c|}{ Total } \\
\cline { 2 - 8 } & $15-24$ & $25-34$ & $35-44$ & $45-54$ & $55-64$ & $>64$ & \\
\hline 2016 & $15,69 \%$ & $45.59 \%$ & $24.02 \%$ & $11.76 \%$ & $2.45 \%$ & $0.49 \%$ & $100 \%$ \\
\hline 2015 & $20.00 \%$ & $46.32 \%$ & $15,79 \%$ & $9.47 \%$ & $7.37 \%$ & $1, .05 \%$ & $100 \%$ \\
\hline 2014 & $11,76 \%$ & $52,10 \%$ & $17,65 \%$ & $13,45 \%$ & $5,04 \%$ & - & $100 \%$ \\
\hline
\end{tabular}

Sumber: passenger exit survey, 2016

Tabel diatas menampilkan 6 kelompok umur untuk wisman Rusia dari usia 15 tahun hingga lebih dari 64 tahun. Jika melihat persentasenya, usia 25-34 tahun yang memiliki persentase yang besar selama tiga tahun berturut-turut. Persentasenya memang menurun, namun tetap lebih besar daripada kelompok usia yang lain. Namun jika dilihat dari pertumbuhannya, pertumbuhan positif kunjungan wisman Rusia ke Indonesia terjadi pada kelompok umur 35-44 tahun dan 45-54 tahun. Angka ini menunjukkan bahwa wisman Rusia yang berkunjung ke Indonesia didominasi oleh wisman yang masuk ke kriteria usia produktif atau untuk istilah sekarang masuk dalam kelompok milenial.

Penelitian Smith (2011) mengemukakan bahwa komputer dan perangkat mobile merupakan perangkat yang umum atau bahkan penting bagi kaum milenial. Kaum ini mengakses media digital dalam kesehariannya dan mampu berkomunikasi serta melakukan pembelian dari berbagai penjual di seluruh dunia. Internet, jaringan sosial, dan dan teknologi interaktif lainnya memungkinkan kaum milenial untuk lebih aktif dalam kreasi dan pengembangan atas suatu produk atau merek. Word-of-mouth atau informasi dari mulut ke mulut saat ini bisa menyebar ke seluruh dunia. Beragam bentuk dari strategi digital marketing akan kembali digunakan dalam penelitian ini seperti; popup ads atau iklan yang muncul tiba-tiba, kupon, e-mail berkala, video pada Youtube, dan iklan pada awal permainan (online games). Pada intinya, penelitian ini akan menjawab promosi yang sesuai untuk wisatawan Rusia, terutama kelompok usia milenial, dan memanfaatkan perangkat pemasaran digital.

Produk menurut (Kotler dan Armstrong., 2012) mendefinisikan produk sebagai apapun yang dapat ditawarkan pada pasar untuk mendapat perhatian, akuisisi, penggunaan, atau konsumsi yang dapat memuaskan keinginan atau kebutuhan. Supaya produk dikenal oleh konsumen, maka diperlukan kegiatan promosi. Promotion mix atau bauran promosi dalam (Kotler dan Armstrong., 2012) merupakan percampuran spesifik dari perangkat promosi yang digunakan perusahaan untuk mengkomunikasikan nilai konsumen secara membujuk dan membangun hubungan konsumen. Perangkat bauran promosi terdiri atas (1) iklan, (2) promosi penjualan, (3) penjualan pribadi, (4) hubungan 
masyarakat, dan (5) pemasaran langsung. Basu, Swastha, dan Irawan (2001) dalam (Atiko et al., 2016) mengemukakan tujuan promosi adalah (1) memodifikasi tingkah laku, (2) memberi tahu, (3) membujuk, dan (4) mengingatkan. Promosi merupakan bentuk komunikasi pemasaran. Menurut (Machfoedz., 2010) dalam (Atiko et al., 2016) komunikasi pemasaran adalah istilah yang digunakan untuk menerangkan arus informasi tentang produk pada pemasar sampai kepada konsumen. Pemasar menggunakan iklan, pemasaran langsung, publisitas, promosi penjualan, dan penjualan langsung untuk memberikan informasi yang mereka harapkan dapat mempengaruhi keputusan pembelian konsumen.

Era ini, penggunaan internet menggiring perubahan dari pemasaran konvensional menjadi pemasaran digital (digital marketing). Digital marketing menurut American Marketing Association (AMA) dalam (Purwana et al., 2017) didefinisikan sebagai aktivitas, institusi, dan proses yang difasilitasi oleh teknologi digital dalam menciptakan, mengkomunikasikan, dan menyampaikan nilai-nilai kepada konsumen dan pihak yang berkepentingan lainnya. (Chaffey., 2013) dalam (Purwana et al., 2017) menyatakan digital marketing sebagai penggunaan teknologi untuk membantu aktivitas pemasaran yang bertujuan untuk meningkatkan pengetahuan konsumen dengan cara menyesuaikan dengan kebutuhan mereka. (Wardhana., 2015) dalam (Purwana et al., 2017) secara sederhana mendefinisikan digital marketing sebagai kegiatan pemasaran yang menggunakan media berbasis internet. Ciri-ciri internet (Roger dalam (Purwana et al., 2017); (1) interactivity atau kemampuan perangkat teknologi memfasilitasi komunikasi antar individu seperti bertatap muka langsung. Komunikasi terjalin sangat interaktif sehingga para partisipan bisa berkomunikasi dengan lebih akurat, efektif, dan memuaskan, (2) demassification atau pesan dapat dipertukarkan kepada partisipan yang terlibat dalam jumlah besar, dan (3) asynchronous atau teknologi komunikasi mempunyai kemampuan untuk mengirimkan dan menerika pesan pada waktu yang dikehendaki setiap peserta. Adanya internet mendorong aktifnya penggunaan media sosial.

Media sosial menurut (Van Dijk., 2013) dalam (Atiko et al., 2016) adalah platform media yang memfokuskan pada ekstitensi pengguna yang memfasilitasi mereka dalam beraktivitas maupun berkolaborasi. Oleh karena itu media sosial dapat dilihat sebagai sebagai medium (fasilitator) online yang menguatkan hubungan antarpengguna sekaligus sebuah ikatan sosial. (Zhu dan Chen., 2015) dalam (Purwana et al., 2017) membagi media sosial ke dalam dua kelompok sesuai dengan sifat dasar koneksi dan interaksi: (1) Profilebased yaitu media sosial berdasarkan profil yang fokus kepada anggota individu. Media sosial kelompok ini mendorong koneksi yang terjadi karena individu tertarik kepada pengguna media sosial tersebut (contoh: Facebook, Twitter, dan Whatsapp). (2) Contentbased yaitu media sosial yang fokus pada konten diskusi, dan komentar terhadap konten yang ditampilkan. Tujuan utamanya adalah menghubungkan individu dengan suatu konten yang disediakan oleh profil tertentu karena individu tersebut menyukainya (contoh: Youtube, Instagram, dan Pinterest).

Sosial strategy menurut (Nino., 2011) dalam (Umami., 2015) merupakan sebuah strategi yang membangun hubungan satu dengan lainnya sesuai dengan tujuan dari media sosial yang memfokuskan kepada hubungan satu orang dengan orang lainnya atau menyambung kembali sebuah hubungan antar manusia. Sosial strategy digunakan sebagai pendekatan pelanggan dengan menggunakan hubungan dengan orang lain yang memfokuskan pada membantu hubungan satu orang dengan orang lainnya dengan tujuan akhir tetap pada target perusahaan yaitu penjualan atau brand awareness. 
Perilaku dan keputusan pembelian konsumen salah satunya bisa dipengaruhi oleh faktor sosial. Lingkungan sosial seperti keluarga, teman, dan rekan bisa dijadikan sumber informasi. Secara teori, sumber informasi bisa berupa sumber formal maupun informal. Menurut (Schiffman dan Kanuk., 2010) sumber informasi formal mewakili baik perusahaan profit atau non-profit, sedangkan sumber informasi informal ini merupakan sesorang dimana penerima pesan mengenal secara pribadi, seperti orang tua atau teman, yang memberikan informasi produk atau nasihat. Berdasarkan pengertian tersebut, sumber informal termasuk jaringan sosial/sosial media dan word-of-mouth atau perkataan langsung dari mulut pemberi berita. Definisi word-of-mouth menurut (Kotler dan Keller., 2012) pengaruh word-of-mouth sebagai komunikasi pribadi tentang produk antara target pembeli dan tetangga, teman, anggota keluarga, dan rekan. Sebagian besar word-of-mouth terjadi secara alamiah. Pengaruh dari word-of-mouth dapat member dampak yang kuat dalam perilaku konsumen. Kata-kata sendiri dan rekomendasi dari teman yang bisa dipercaya, rekan, dan konsumen lain dinilai lebih kredibel/bisa dipercaya daripada yang berasal dari sumber formal. Sumber informal yang ditemui konsumen secara online seperti jaringan sosial dan ruang bicara (chat room) memiliki pengaruh yang kuat dalam perilaku konsumsi karena dianggap tidak mengambil keuntungan apapun atas rekomendasi yang diberikan. Konsumen bergantung pada word-of-mouth dalam memilih restoran, tujuan wisata dan hotel, buku, film, dan produk/jasa lainnya. Perkembangan teknologi mendorong konsumen untuk berbagi pengalaman mereka dengan orang lain secara visual dan verbal sehingga muncullah istilah electronic word-of-mouth (e-WOM). Termasuk dalam e-WOM seperti jaringan sosial, komunitas merek, blog, dan papan pesan konsumen. Jaringan sosial online atau yang lebih familiar dengan media sosial dapat didefinisikan sebagai "Online social networks or online social communities-blogs, social networking web sites, or even virtual worlds- where people socialize or exchange information and opinions" (Kotler dan Keller., 2012). Artinya, jaringan sosial online atau komunitas sosial online- berupa blog, situs jaringan sosial, atau bahkan dunia visualdimana orang-orang bersosialisasi dan bertukar informasi serta opini. Terdapat tiga dimensi yang mendasari koneksi konsumen dalam e-WOM (Schiffman dan Kanuk., 2010) yaitu: (1) tie strength atau kekuatan ikatan sebagai tingkat kedekatan dan frekuensi kontak antara pencari dengan pemberi informasi (2) similarity atau kesamaan diantara anggota kelompok dalam hal demografi dan gaya hidup (3) source credibility atau kredibilitas sumber dimana persepsi pencari informasi terhadap keahlian pemberi informasi dalam memberikan nasihat.

Digital tourism atau wisata digital dalam (Benyon et al., 2013) dapat didefinisikan sebagai pendukung digital atas pengalaman wisatawan sebelum, pada saat, dan dan setelah aktivitas perjalanan. Hal ini bisa menjadi; sistem rekomendasi untuk membantu seseorang dalam mencari akomodasi yang cocok pada saat perencanaan liburan dan aplikasi pemandu wisata pada ponsel untuk melihat foto-foto liburan. Konsep digital tourism bukanlah hal baru dan sudah membanjiri aktivitas online dalam perencanaan liburan seperti melalui Expedia dan Tripadvisor, dan Facebook.

\section{METODE PENELITIAN}

Metode penelitian untuk kajian ini adalah metode eksploratif untuk memberikan pemahaman dan pengertian secara mendalam terhadap promosi pariwisata untuk wisman Rusia. Jenis data yang didapat adalah data kuantitatif yang terdiri tabel, angka, rata-rata, 
dan persentase. Sumber data yang digunakan merupakan data sekunder dari berberbagai sumber yang sudah dikumpulkan oleh tim promosi mancanegara Kementrian Pariwisata. Teknik analisis data yang digunakan adalah teknik deskriptif kualitatif.

\section{HASIL PENELITIAN DAN PEMBAHASAN}

Kementrian Pariwisata melalui divisi promosi mancanegara akan menetapkan strategi sesuai dengan profil pasar yang dituju. Strategi yang secara umum yang ditetapkan untuk promosi mancanegara adalah; strategi pemasaran dengan DOT (destination, origin, time); strategi promosi melalui BAS (branding, advertising, selling); dan strategi media yang disebut POS (paid, owned, social). Kajian ini hanya akan membahas POS terutama social atau sosial media. Jika melihat kembali data diatas dapat terlihat profil wisatawan Rusia adalah pengguna internet, pengguna perangkat mobile termasuk ponsel dan tablet, serta menggunakannya untuk aktivitas sosial media. Tetap berpatokan pada data, sosial media yang diakses 39\% warga Rusia adalah Vk (Vk.com) sejenis Facebook versi Rusia. Media sosial kedua, Odnoklassniki (Ok.ru) disukai sebanyak 32\% dan Facebook di urutan ke-3 dengan $24 \%$ pengguna dari seluruh warga Rusia. Jika disandingkan kembali dengan definisi media sosial menurut Van Dijk (2013) dalam Atiko dkk (2016) adalah platform media yang memfokuskan pada ekstitensi pengguna yang memfasilitasi mereka dalam beraktivitas maupun berkolaborasi maka promosi melalui ketiga media sosial diatas harus dilakukan.

Divisi promosi mancanegara Rusia harus membuat akun Wonderful Indonesia di Vk.com lalu menjaring para wisatawan yang sudah dan potensial untuk berkunjung Indonesia, serta rajin mengunggah foto dan video tentang Indonesia terutama wisata budaya perkotaan dan pedesaan serta keindahan bahari karena kedua hal inilah yang menjadi alasan wisman Rusia datang berlibur ke Indonesia.

Ada beberapa alasan memilih Vk.com sebagai media promosi karena; Vk.com merupakan sosial media paling popular di Rusia, melalui VK.com dapat melihat (stream) dan berbagi file, rakyat Rusia percaya Vk.com lebih baik daripada Facebook, desain laman jarang berubah, dan populer untuk pengguna yang berusia muda sesuai dengan target wisman Rusia ke Indonesia. Selanjutnya untuk Odnoklassniki cocok untuk menjaring wisman yang berusia 35-54 tahun yang juga masuk dalam kelompok umur wisman potensial.

Laman Odnoklassniki merupakan media yang menghubungkan kembali pertemana yang sudah lama terpisah. Sosial media ini $69 \%$ penggunanya adalah wanita yang notabene suka bercerita. Pengalaman libur ke Indonesia dapat dituangkan dalam laman ini dan menjadi promosi word-of-mouth sesuai dengan perilaku wisman Rusia yang memang lebih percaya cerita dari teman daripada situs umum atau iklan. Sosial media yang terakhir adalah Facebook. Promosi tetap melalui sosial media ini karena di Rusia Facebook digunakan untuk diskusi yang berkaitan dengan bisnis. Jika dikaitkan dengan pariwisata, promosi via Facebook cocok dilakukan untuk menjaring bisnis perjalanan atau agen perjalanan karena masih ada juga $(4,21 \%)$ wisman Rusia yang pergi berlibur dengan paket perjalanan yang ditawarkan agen perjalanan wisata. 
Melalui ketiga sosial media diatas, strategi Kemenpar untuk memberikan wisatawan pengalaman yang superior serta meningkatkan pengalaman wisata digital (digital tourism) dapat lebih mudah terwujud. Digital tourism atau wisata digital dalam Benyon dkk (2013) dapat didefinisikan sebagai pendukung digital atas pengalaman wisatawan sebelum, pada saat, dan dan setelah aktivitas perjalanan.

Tiga platform sosial media Rusia diatas dapat memenuhi kriteria digital tourism seperti definisi diatas. Pertama, wisatawan dapat merencanakan liburannya dengan mencari, melihat, atau membaca hasil tulisan, foto, dan video yang sudah diunggah wisman Rusia lainnya sehingga calon wisman ini setidaknya sudah ikut merasakan pengalaman liburan sebelum liburan yang sebenarnya. Kedua, wisman Rusia yang sedang berada di Indonesia dapat langsung mengunggah pengalaman liburannya, juga lewat foto dan video, sehingga pengalaman wisman pada saat liburan bisa tersimpan dalam akun sosial medianya. Ketiga, wisman Rusia dapat menceritakan kembali pengalaman liburannya setelah selesai berlibur dengan demikian pengikut (followers) wisman dapat membaca, menyaksikan, dan menyimpan informasi tersebut untuk perencanaan liburan yang akan datang. Walaupun Vk.com dan Odnoklassniki merupakan media sosial utama wisatawan Rusia, bukan berarti tidak menjadikan Instagram sebagai platform promosi digital untuk wisatawan Rusia. Kajian penelitian Smith (2011) menyimpulkan bahwa kaum milenial lebih menyukai beberapa bentuk dari iklan digital daripada bentuk yang lain. Strategi pemasaran memang lebih efektif untuk menarik perhatian kaum milenial, termotivasi untuk mengunjungi website berulang-ulang, dan mengharapkan review secara online.

Iklan Wonderful Indonesia dalam bentuk digital ditampilkan dalam bentuk utuh pada Youtube bukan dalam bentuk pop-up atau yang muncul tiba-tiba, mengganggu pemirsa, dan berujung ditutup atau tidak dilihat. Untuk website tampilan lebih berwarna dengan warna-warna yang terang. Promosi digital lain adalah kupon atau voucher online yang dapat digunakan wisatawan milenial ketika berkunjung ke Indonesia. Kupon juga disesuaikan dengan perilaku mereka, bahkan dengan setuhan pribadi atau personal touch. Penelitian Indika dan Jovita (2017) juga meneliti tentang penggunaan media sosial, yaitu Instagram, sebagai sarana promosi untuk obyek wisata Floating Market, Lembang. Instagram memiliki dimensi context (setting atau latar belakang), communication (pesan), collaboration (kerjasama), dan connection (link atau koneksi) yang kurang lebih sama dengan platform media sosial lainnya. Penelitian tersebut menyimpulkan bahwa media sosial Instagram dengan komunikasi foto yang dikemas secara kreatif menjadi salah satu faktor yang cukup penting dalam menarik perhatian konsumen akan tempat tujuan wisata.

Aplikasi media sosial Instagram yang menonjolkan sharing foto atau gambar terbukti punya korelasi kuat dalam memengaruhi minat beli konsumen. Mengacu pada penelitian diatas, walaupun Vk.com dan Odnoklassniki merupakan media yang disukai wisatawan Rusia, tidak menutup kemungkinan bagi Badan Promosi Wisata untuk tetap melakukan promosi digital dengan akun Instagram. 


\section{KESIMPULAN DAN SARAN}

Penetrasi internet dan tingkat penggunaan sosial media rakyat Rusia berada di peringkat 14 dan 15 dunia. Perangkat mobile juga digunakan untuk mengakses sosial media. Sosial media seperti Vk, Odnoklassniki, dan Facebook digunakan untuk membagi foto, video, dan ulasan termasuk tentang liburan. Wisatawan Rusia yang merencanakan liburan cenderung mempercayai informasi melalui word-of-mouth dan situs oleh karena itu promosi secara digital melalui sosial media dinilai sesuai untuk meningkatkan jumlah kunjungan wisman Rusia ke Indonesia. Kementrian Pariwisata melalui badan promosi mancanegara harus memiliki akun di 3 sosial media populer di Rusia yaitu Vk, Odnoklassniki dan Facebook sehingga kriteria untuk melakukan digital tourism (pariwisata digital) dapat terpenuhi. Konten promosi disesuaikan dengan usia pengguna media sosial serta ketertarikan wisman Rusia jika berlibur ke Indonesia. Unggah foto dan video yang berkaitan dengan wisata budaya desa maupun kota serta keindahan bahari Indonesia. Saran yang bisa diberikan untuk promosi pasar Rusia adalah dengan merambah sosial media lain seperti; Rutube (sejenis Youtube dari Rusia) untuk berbagi video dan Instagram (instagramrussia) dengan menggaet pengikutnya (followers) untuk mengikuti akun Instagram promosi wisata Indonesia @indtravel. Melalui sosial media diatas strategi digital tourism untuk menciptakan tourist experience dapat terlaksana dan dapat mencapai target wisman yang diharapkan setiap tahunnya.

\section{UCAPAN TERIMA KASIH}

Peneliti mengucapkan terima kasih kepada Kementrian Pariwisata Indonesia (bidang promosi luar negeri), Ibu Ismayanti, A.Par, M..Sc, dan Universitas Sahid atas kesempatan yang diberikan sehingga terciptanya artikel ini.

\section{DAFTAR PUSTAKA}

Atiko, Gita dkk. (2016). Analisis Strategi Promosi Pariwisata Melalui Media Sosial Oleh Kementrian Pariwisata RI (Studi Deskriptif Pada Akun Instagram @ INDTRAVEL). Jurnal Sosioteknologi. Volume 15 No.3: 378.

Benyon, David et al. (2013). Presence and Digital Tourism. Springer AI \& Soc DOI 10.1007/s00146-013-0493-8.

Indika, Deru R. \& Jovita, Cindy. (2017). Media Sosial Instagram Sebagai Sarana Promosi Untuk Meningkatkan Minat Beli Konsumen. Jurnal Bisnis Terapan Volume 01, No 01. [Online] tersedia di: http://journal.ubaya.ac.id/index.php/JIBT/article/download/296/192/. [Diakses pada tanggal 16 Januari 2019].

Kotler, P \& Armstrong, G. (2012). Principles of Marketing. $14^{\text {th }}$ edition. Essex: Pearson. 
Kotler, P \& Keller, L. K. (2012). Marketing Management, 14th Edition. New Jersey: Pearson Education

Purwana, ES \& Dedi dkk. (2017). Pemanfaatan Digital Marketing Bagi Usaha Mikro, Kecil, dan Menengah (UMKM) Di Kelurahan Malaka Sari, Duren Sawit. Jurnal Pemberdayaan Masyarakat Madani (JPMM). Volume 1 No.1: 1. Schiffman, L, G. $\&$ Kanuk, L, L. (2010). Consumer Behavior, $10^{\text {th }}$ edition. New Jersey:Pearson

Smith, K, T. (2011). Digital Marketing Strategies that Millenials Find Appealing, Motivating, or Just Annoying. Journal of Strategic Marketing. [Online] tersedia di: https://www.google.com/search?safe=strict\&source=hp\&ei=Sqc9XNT_A5XHrQ GwuIGgAw\&q=digital+promotion\%2C+journal\&btnK=Google+Search\&oq=digi tal+promotion\%2C+journal\&gs_l=psyab.3..33i160.1360.17990..18520...3.0..3.20 $10.9267 .7 \mathrm{j} 15 \mathrm{j} 4 \mathrm{j} 0 \mathrm{j} 2 \mathrm{j} 0 \mathrm{j} 1 \mathrm{j} 0 \mathrm{j} 1 \mathrm{j} 1 \ldots \ldots . . . . .1 . . \mathrm{gws}-$ wiz....0..0i131j0j35i39j0i203j0i22i10i30j0i22i30j33i21j33i22i29i30j33i10.PX8Y Tx2jiyg. [Diakses pada tanggal 15 Januari 2019].

Smith, B. (2016). The Top 8 Russian Social Networks (And What Makes Them Great). [Online] Tersedia di: https://www.makeuseof.com/tag/top-8-russian-socialnetworks-makes-great/ [Diakses pada tanggal tanggal 5 April 2018].

Smith, B. (2016). 10 Incredible VK Facts You Should Know (AKA Russia's Facebook). [Online] Terdapat di: https://www.makeuseof.com/tag/10-incredible-vk-facts-youshould-know-aka-russias-facebook/ [Diakses pada tanggal 5 April 2018].

Umami, Z. (2015). Social Strategy Pada Media Sosial Untuk Promosi Pariwisata Daerah Istimewa Yogyakarta. Jurnal Interaksi. Volume 4 No.2: 195-201. 